\section{Elveblindhet kan elimineres}

Elveblindhet skyldes den parasittære rundormen Onchocerca volvolus, som infiserer mennesker via bitt av svartfluer av slekten Simulium, som klekker eggene sine $i$ elver med rask vannføring. Onchocercalarvene (mikrofilarier) slår seg ned i subkutant vev og utvikler seg til voksne ormer, som viser seg som subkutane knuter. Hunnormene produserer nye mikrofilarier, som migrerer til andre vev, blant annet til øynene. Der kan de gi en inflammasjon som kan føre til blindhet, hvilket har gitt sykdommen dens navn. Livssyklusen opprettholdes ved at mikrofilariene i huden blir inntatt av nye blodsugende svartfluer.

Det bredspektrede antiparasittære midlet ivermectin dreper mikrofilarier, men ikke voksne ormer. Én enkeltdose er tilstrekkelig til å drepe $98 \%$ av mikrofilariene innen to uker (1). Årlig administrering av ivermectin til en risikobefolkning kan dermed redusere antall mikrofilarier i så stor grad at man i neste omgang begrenser antall nysmittede. Dette er hovedstrategien i The African Programme for Onchocerciasis Control, som har vist god effekt og er mulig fordi Merck donerer ivermectin gratis (2). En studie fra Mali og Senegal har demonstrert at når forekomsten av Onchocerca er blitt redusert tilstrekkelig, vil sykdommen forbli sjelden også etter at behandlingen avsluttes (2). Det betyr at eliminering av sykdommen i endemiske områder er mulig.

Over 37 millioner mennesker er infiserte med Onchocerca. Effekten av ivermectinprogrammene forutsetter at de ikke avsluttes for tidlig. Kampanjene har i stor grad vært finansiert av frivillige organisasjoner og Verdensbanken, men planen har vært at lokale myndigheter skal overta. Da så skjedde i to stater i Nigeria i 2003, ble antallet behandlet med ivermectin mer enn halvert (3). Frafallet ble reversert da internasjonale organisasjoner gjenopptok finansieringen.

\section{Kristoffer Brodwall}

kristoffer.brodwall@gmail.com

Barneavdelingen

Ålesund sjukehus

\section{Litteratur}

1. Basáñez MG, Pion SD, Boakes E et al. Effect of single-dose ivermectin on Onchocerca volvulus: a systematic review and meta-analysis. Lancet Infect Dis 2008; 8: 310-22.

2. Diawara L, Traoré MO, Badji A et al. Feasibility of onchocerciasis elimination with ivermectin treatment in endemic foci in Africa: first evidence from studies in mali and senegal. PLoS Negl Trop Dis 2009; 3: e497.

3. Rakers LJ, Emukah E, Onyenama J et al. Sustainability of ivermectin distribution programmes. Lancet 2009; 374: 785-6.

\title{
Tusenårsmål 5 - reduksjon av mødredødelighet
}

\author{
Ett av FNs tusenårsmål er eksplisitt og spesifikt rettet mot mødredøde- \\ lighet; det vil si kvinner som dør under svangerskap, fødsel, abort eller \\ i den første måneden etter at graviditeten er avsluttet. Mødredødelighet \\ er en av indikatorene på global ulikhet og er nesten eliminert i vår del \\ av verden, mens de verst rammede landene har om lag 1000 ganger \\ høyere dødelighet. Disse tallene har vært nærmest uendret i over 20 år. \\ Fremdeles dør mer enn en halv million kvinner årlig i forbindelse med \\ svangerskap eller fødsel.
}

\section{Johanne Sundby}

johanne.sundby@medisin.uio.no Seksjon for internasjonal helse Institutt for allmenn- og samfunnsmedisin Universitetet i Oslo

Postboks 1130 Blindern 0317 Oslo

I en toneangivende artikkel fra 1985 reiste Maine \& Rosenfield spørsmålet «Where is the $\mathrm{M}$ in $\mathrm{MCH} \gg-$ eller hvor er moren i morbarn-helsetjenestene? (1). I 1987 ble konseptet «Safe Motherhood» lansert, men effekten av tiltaket uteble. Mødredødeligheten sank ikke. I 2005 ble partnerskapet for å redde mødre og barn startet opp mellom ulike FN-organisasjoner og verdensbanken. UNICEF, WHO og UNFPA (United Nations Population Fund) har flere ganger gitt ut estimater over mødredødeligheten på land- og regionnivå. Resultatene er nedslående: I de fattigste landene, og især i Sør-Asia og Afrika sør for Sahara, har det vært liten eller ingen fremgang $(2-4)$.

\section{Forekomst}

Vestlige land har gjerne en mødredødelighet på under ti dødsfall per 100000 levende fødte, mens tilsvarende tall for fattige land i konflikt kan være over 1500 dødsfall per 100 000. Det er ikke lett å estimere dødeligheten, fordi det absolutte tallet vil være lavt, og estimatene baserer seg mye på indirekte målemetoder som surveyer og befolkningsutvalg, ikke på en nitid føring av vitale data (2).

Tusenårsmål 5 sier at mødredødeligheten skal reduseres med $75 \%$ fra 1990 til 2015. Noen land har klart en vesentlig reduksjon, men globalt ligger man langt fra å nå målet, og i noen få land, især de fattige landene og land i konflikt, øker dødeligheten. Mer enn en halv million kvinner dør hvert år, omtrent $13 \%$ av disse pga. illegale og medisinsk utrygge provoserte aborter, resten relatert til fødsler (tab 1).

\section{Hva dør kvinnene av? Underliggende forhold}

Dødeligheten er høyest i land som har dårlige helsetjenester. Kvinners status, lav sosioøkonomisk utvikling og fattigdom er medvirkende $(4,5)$. Landsbygda er rammet hardere enn byene, og fattige land hardere enn rike land. Men også to land med samme sosioøkonomiske status kan ha ulik mødredødelighet, avhengig av om det satses på mor-barn-helsetjenester. Malaysia og Sri Lanka er eksempler på relativt fattige land, men som har klart å redusere sin mødredødelighet (2).

Fattige lag av befolkningen er rammet hardest, og ofte også kvinner fra minoriteter, kvinner på flukt, ugifte kvinner, unge kvinner, kvinner uten utdanning og kvinner uten egen inntekt. Mange steder har kvinner liten autonomi og kan ikke fatte beslutninger om egen kropp og helse eller dra fra hjemmet uten anstand. Noen kvinner lever i samliv preget av vold, trusler og overgrep, eller er utsatt for voldtekt, vold i svangerskapet eller har opplevd seksuelle overgrep. Når kvinner i slike situasjoner trenger tillatelse til å søke hjelp, kan det hende hun ikke kommer seg på sykehus. Kommer hun seg dit, kan det hende det kreves betaling for tjenestene, penger hun må be sine mannlige slektninger om.

\section{Sykdom og svangerskapskomplikasjoner} Infeksjoner som malaria er farligere for gravide, og de får det lettere fordi immunforsvaret endres av graviditeten. Hiv/aids og underlivsinfeksjoner blant unge gravide er epidemisk i deler av Afrika. I de verst rammede landene, som Botswana og SørAfrika, har man funnet at opp mot 20-40\% av de unge gravide er hivsmittet (6). Mange kvinner er kronisk anemiske og vil ha større risiko for å dø av blødningskomplikasjoner 